This article is (c) Emerald Group Publishing and permission has been granted for this version to appear here (https://radar.brookes.ac.uk/radar/access/home.do) under the Creative Commons license CC-BY-NC.

Emerald does not grant permission for this article to be further copied/distributed or hosted elsewhere without the express permission from Emerald Group Publishing Limited.

See more at:

http://www.emeraldgrouppublishing.com/authors/writing/author_rights.htm\#sth ash.rWXYiHpe.dpuf

Rhona Sharpe (2014), What Does it Take to Learn in Next Generation Learning Spaces?, in Kym Fraser (ed.) The Future of Learning and Teaching in Next Generation Learning Spaces (International Perspectives on Higher Education Research, Volume 12), Emerald Group Publishing Limited, pp.123146

http://www.emeraldinsight.com/books.htm?chapterid=17115441

\title{
What does it take to learn in next generation learning spaces?
}

Rhona Sharpe, Oxford Brookes University

\begin{abstract}
This chapter identifies the attributes that learners need in order to learn effectively in new technology rich educational environments. There are a number of different ways of synthesising the findings from this emerging literature which relies heavily on qualitative research. This chapter reports on a literature review which adopted a deliberately interpretative qualitative meta-analysis, synthesising the findings from 15 key studies. As such, the chapter demonstrates a way of reviewing and compiling current research. The synthesis resulted in the identification of six attributes that learners need to do well in next generation learning spaces. These are: engaged, connected, confident, adaptable, intentional and self-aware. Although some of these attributes are applicable to all learning contexts, those of being connected, confident, adaptable and intentional seem to be particularly important in learning in next generation learning spaces. The challenge is to design learning activities that encourage and reward the development of these attributes. The hope is that through both its findings and its method, this chapter provokes debate on what it now means to be a successful learner in today's technology rich world.
\end{abstract}

Keywords: meta-analysis, literature review, learning, attributes, learner experience 


\section{Introduction}

The chapters in this section have explored the teaching, learning and assessment activities that will enable us to unleash the potential of next generation physical and online learning spaces. Fraser and Ling in this volume remind us to focus on the learner in our design, with recommendations informed by theoretical understandings of how students learn through constructivism and situated learning. Similarly Crisp in this volume encourages assessment approaches informed by evidence of learner needs. Putting the learners at the centre of our design is clearly important when designing for learning in the new spaces that are explored in this book. In order to plan learning activities that will help develop effective learners, we need to have a clear picture of what it is that learners do in such environments, and particularly, what it is that successful learners do.

Three recent models of digital literacy might be a starting point. First, the European Commission's Joint Research Centre consulted with experts and produced a model of Digital Competence defined as "involving the confident and critical use of Information Society Technology (IST) for work, leisure and communication" (AlaMutka, 2011, p.5). Through its exposition of 'critical and confident use', this model recognises that having IT skills is not sufficient. Despite using the title of 'competence' this report concludes that we need to move our attention from access to technology to understanding how individuals can benefit from their use of technology in meaningful ways. Consequently their model encompasses three areas:

- instrumental knowledge and skills for digital tool and media usage;

- advanced skills and knowledge for communication and collaboration, information management, learning and problem-solving, and meaningful participation, and;

- attitudes to strategic skills usage in intercultural, critical, creative, responsible and autonomous ways.

The European Commission's model reflects a shift in conceptualising the requirements to learn effectively in a digital age from digital skills to appropriate use. Such a shift can also be seen in the iterative development of the Seven Pillars model developed by the Society of College, National and University Libraries in UK and Ireland (SCONUL). This was first published in 1999 as a framework for 'information skills'. It was updated in 2011 and re-titled 'information literacy', and in 2012 a further framework was added: the seven pillars of information literacy through a digital literacy lens (SCONUL, 1999, 2012). The 2012 framework includes statements related to digital identity (the need to consider the digital self and one's online presence), confidence (confidently use the digital media appropriate for presentation) and personalisation (personalise the digital environment according to need).

The third and final model arose from a series of studies funded by the JISC in the UK under its Learner Experiences of E-learning programmei.Like the European Commission's report described above, the JISC programme also found that access and skills are necessary but not sufficient to explain successful learning with technology. In order to explain what had been discovered about how learners progress towards effective use of technology for learning, a developmental model was created with four layers: access, skills, strategies and creative appropriation (Sharpe \& Beetham, 2010). The model emphasises that the attributes and actions of effective learners are built upon a set of technology-based practices, which in turn 
require appropriate skills and functional access to the relevant technologies. The description originally given of creative appropriation was
At this stage [of the model] the learner has 'creatively appropriated' available technologies and learning opportunities to meet his/her own goals. At this stage, personal attributes and styles come to the fore, as do personal motivations for learning, and beliefs about both learning and technology. (Sharpe \& Beetham, 2010, p.92)

This model set out what was known about the strategies, beliefs, behaviours and attitudes of learners, but was rather vague about the attributes that might be important. The model says little about what drives some learners to creatively appropriate the technology they have available to them in ways that support their study. Indeed it can be quite difficult to elicit these, despite being aware of their importance. For example, Brown \& Czerniewicz (2007) explored the relationship between access to and use of technology to support learning in South Africa. Although their findings show, as expected, that students with poor access to technology make less use of technology for learning, the reverse is not true. That is, high access does not guarantee high use. Brown and Czerniewicz used the concept of agency to explain why some students make more use of their access than others. We also know from studies based on the technology acceptance model, that learners' intentions to use technology influence their patterns of use (Liao \& Lu, 2008; Liaw, 2008; Edmunds, 2010). Specifically, learners are more likely to use technology if they are more satisfied with it and if they perceive it to be useful.

Learner experience research offers a way of exploring learner attributes furtherii. Learner experience research has developed rapidly within the field of learning technology in the last few years. New ways of eliciting, capturing and analysing learners experiences are being tried and researchers are showing a growing confidence in applying these methods. Learner experience approaches use qualitative, exploratory, and often participatory, research methods to elicit learner experiences and generate rich descriptions which foreground learners' perspectives, beliefs and behaviours. Reviewing studies that have utilised such approaches should help us to uncover what it is that distinguishes successful from less successful learners. Given the dominant qualitative methods used, such studies should be particularly helpful in describing the less tangible aspects of digital literacy that have appeared in recent models of digital literacy such as attitudes and attributes.

A final point before embarking on the review of learner attributes, is that this is not to dismiss the role of context. It is clear that both local contextual factors such as course design (Kirkwood \& Price, 2005), and wider social and contextual factors (Lea \& Jones, 2011) shape learners' use of technology. Indeed, the review which follows might be framed within Biggs's (1989) 3Ps model, where the presage factors of learner attributes, instructional attributes, and contextual attributes, are all understood to have an influence on practice. However, here we are only interested in one of those presage factors - learner attributes.

\section{The review}

This review of literature is driven by the research question 'What can learner experience research tell us about the attributes of successful online learners?'. This review will inform models of digital literacy, which are already showing signs of moving beyond specification of skills and competencies. It draws on qualitative research arising from the field of learners' experiences of e-learning. Although 
learner experience research has exposed and given a platform for authentic learners' voices, it has been criticised for relying on small-scale research, and it has been a challenge to integrate the results from many studies in ways which produce meaningful advice for practitioners.

Meta-analyses have played an important role in other emerging disciplines (e.g. in cognitive neuroscience see Cabeza \& Nyberg, 2000) because they can test the reliability of our findings, by averaging out the results from many studies, each of which may have used slightly different data collection methods or research questions. The influence of idiosyncratic features of individual studies are lessened in a meta-analysis where what is of interest are the findings which are common to all studies. Qualitative meta-analyses allow us to draw stronger inferences from the review then could be concluded from a single study. The methodology for this review is a qualitative systematic review drawing on the interpretative meta ethnography approach used by Noblit and Hare (1988) and Sharpe and Savin-Baden (2007). This method allows for comparison, analysis and interpretations of previous research to be made in order to integrate the findings from qualitative, small-scale studies.

\section{Paper search}

A number of different search terms were tried initially. The terms that were found to produce the papers which most closely matched the research questions for the review were 'educational technology' AND 'learner experience'. These search terms were applied to the full text of the article, limiting the search to peer reviewed publications and to those published in the last five years. The number of papers returned from keyword searches are shown in Table 1.

Table 1: Databases, search terms and number of hits

\begin{tabular}{|l|l|}
\hline Database & $\begin{array}{l}\text { Number of } \\
\text { papers returned }\end{array}$ \\
\hline Academic Search Complete & 74 \\
\hline Applied Social Sciences Index and Abstracts & 8 \\
\hline Australian Education Index & 62 \\
\hline BEI & 2 \\
\hline $\begin{array}{l}\text { Cumulated Index to Nursing and Allied Health } \\
\text { Literature (CINAHL) }\end{array}$ & 0 \\
\hline ERIC & 5 \\
\hline Ingenta Connect & 0 \\
\hline PsychINFO & 1 \\
\hline
\end{tabular}

In addition to searching databases, several other methods were used including scanning bibliographies of articles found, hand searching of contents pages of relevant journals, following up reference lists, and consulting with experts in the field. Each paper was read in full and evaluated against the criteria in Table 2. Papers that were excluded at this stage were excluded most often because they did not have a qualitative component to their data collection and/or because they did not discuss learner attributes. A summary of the final set of 15 studies is given in Table 3 . It is noted that the final set included studies of technology use in fully online, blended and face-to-face contexts.

Table 2: Inclusion and exclusion criteria

\begin{tabular}{|l|l|l|}
\hline Criteria & Include studies & Exclude studies \\
\hline 1. Context & $\begin{array}{l}\text { Technology use in a learning } \\
\text { context }\end{array}$ & $\begin{array}{l}\text { Technology use not in a learning } \\
\text { context }\end{array}$ \\
\hline 2. Topic & Attributes of learners, e.g. & Evaluation of a course e.g. course \\
\hline
\end{tabular}




\begin{tabular}{|l|l|l|}
\hline & $\begin{array}{l}\text { intentions, conceptions, beliefs. } \\
\text { Practices or strategies of } \\
\text { learners that were effective, } \\
\text { from which attributes can be } \\
\text { inferred. } \\
\text { Studies that identified attributes } \\
\text { and/or practices that contributed } \\
\text { to effective learning in digital } \\
\text { environments. }\end{array}$ & $\begin{array}{l}\text { design features. } \\
\text { Examination of learner access, use } \\
\text { or skills. }\end{array}$ \\
\hline 3. Location & $\begin{array}{l}\text { Worldwide but published in } \\
\text { English }\end{array}$ & \\
\hline 4. Level & $\begin{array}{l}\text { Adults (18+) in tertiary or higher } \\
\text { education }\end{array}$ & $\begin{array}{l}\text { Primary (K-12), secondary, adult } \\
\text { education, basic skills. }\end{array}$ \\
\hline 5. Date & Published 2008 or later & Published prior to 2008 \\
\hline 6. Design & $\begin{array}{l}\text { Primary research } \\
\text { Qualitative research design e.g. } \\
\text { case studies } \\
\text { Mixed method with qualitative } \\
\text { data e.g. interviews, focus } \\
\text { groups, observation logs/diaries. }\end{array}$ & $\begin{array}{l}\text { Review paper, opinion piece, } \\
\text { anecdotal evidence. } \\
\text { Primary research which collects and } \\
\text { analyses only quantitative data. }\end{array}$ \\
\hline $\begin{array}{l}\text { 7. Quality, } \\
\text { robustness }\end{array}$ & $\begin{array}{l}\text { Peer reviewed, journal articles } \\
\text { and theses }\end{array}$ & $\begin{array}{l}\text { Non peer reviewed publications, } \\
\text { conference papers and proceedings }\end{array}$ \\
\hline
\end{tabular}


Table 3. Summary of papers included in final set

\begin{tabular}{|c|c|c|c|}
\hline Paper & Leaners and their context & Methods & Summary of learner attributes \\
\hline $\begin{array}{l}\text { Anagnostopoulou, } \\
\text { Parmar \& Priego- } \\
\text { Hernandez (2009) }\end{array}$ & $\begin{array}{l}\text { First year undergraduates from a } \\
\text { UK university. Compared student } \\
\text { 'withdrawers' and 'persisters'. } \\
\text { Questions focused on personal } \\
\text { experience, perceptions of learning } \\
\text { and the use of technology in } \\
\text { relation to learning. }\end{array}$ & $\begin{array}{l}\text { Telephone interviews (withdrawn } \\
\text { students, } n=42 \text { ) and questionnaires (not } \\
\text { withdrawn students } n=130 \text { ). Thematic } \\
\text { analysis. }\end{array}$ & $\begin{array}{l}\text { Retained group showed awareness of how they } \\
\text { learn as individuals. They reported learning most } \\
\text { effectively through active participation with their } \\
\text { peers and in collaboration with their tutors. }\end{array}$ \\
\hline $\begin{array}{l}\text { Andrews \& Tynan } \\
\text { (2012) }\end{array}$ & $\begin{array}{l}\text { Distance learners in Australia, } \\
\text { purposively sampled to include } \\
\text { those working full and part-time. } \\
\text { Questions asked about the } \\
\text { experience of technology for } \\
\text { teaching and learning. }\end{array}$ & $\begin{array}{l}\text { Phenomenological approach, using the } \\
\text { day experience method, charting the } \\
\text { week's activities, photos of learning } \\
\text { spaces and focus groups ( } n=12) \text {. }\end{array}$ & $\begin{array}{l}\text { Individualness, connectedness, mobility and } \\
\text { resourcefulness. }\end{array}$ \\
\hline $\begin{array}{l}\text { Brown, Hughes, } \\
\text { Keppell, Hard \& Smith } \\
\text { (2013) }\end{array}$ & $\begin{array}{l}\text { First-time distance learners in } \\
\text { Australasia. Compared data from } \\
\text { "support seekers" with "lone } \\
\text { wolves". }\end{array}$ & $\begin{array}{l}\text { A pre- }(n=62) \text { and post- }(n=57) \\
\text { semester survey and a video diary } \\
\text { phase }(n=20) \text {. }\end{array}$ & $\begin{array}{l}\text { Seeking contact with lecturers, enjoying the } \\
\text { opportunity to make a personal connection with } \\
\text { lecturers, a deep approach to learning. }\end{array}$ \\
\hline $\begin{array}{l}\text { Buckley, Pitt, Norton \& } \\
\text { Owens }(2010)\end{array}$ & $\begin{array}{l}\text { First year undergraduate Sport } \\
\text { Studies students enrolled on a } \\
\text { blended module, which makes use } \\
\text { of the VLE email and online } \\
\text { submission of assignments. }\end{array}$ & $\begin{array}{l}\text { Approaches and Study Skills Inventory } \\
\text { for Students }(n=144) \text {. Focus group } \\
\text { interviews }(n=19) \text {, with inductive } \\
\text { thematic analysis. }\end{array}$ & $\begin{array}{l}\text { Learners saw discussion forums as a place which } \\
\text { could help them develop and learn new skills, and } \\
\text { where they could share personal experiences and } \\
\text { reflect upon themselves as learners. }\end{array}$ \\
\hline Dujardin (2009) & $\begin{array}{l}\text { Mature postgraduate student on a } \\
\text { fully online Master's module on } \\
\text { research design. }\end{array}$ & $\begin{array}{l}\text { Ethnography. Key informant: multiple } \\
\text { interviews with one student over } 5 \\
\text { months }\end{array}$ & $\begin{array}{l}\text { Key informant described as being 'fluent in her } \\
\text { online self-presentation, she valued her } \\
\text { interactions with others and contributed to the } \\
\text { overall sociability of the VLE'. }\end{array}$ \\
\hline $\begin{array}{l}\text { Ellis, Bluic \& Goodyear } \\
\text { (2012) }\end{array}$ & $\begin{array}{l}\text { First year foundational pharmacy } \\
\text { course in an Australian } \\
\text { metropolitan university. The } \\
\text { relevant learning activities were a } \\
\text { field trip and an online investigative } \\
\text { task. }\end{array}$ & $\begin{array}{l}\text { Phenomenographic approach. Survey } \\
\text { of conceptions and approaches to } \\
\text { learning through enquiry }(n=124) \text { and } \\
\text { interviews }(n=22) \text {. }\end{array}$ & $\begin{array}{l}\text { Deep approach to learning. Being active, critically } \\
\text { engaged, and aware of the intrinsic value of } \\
\text { authentic contexts/discovery. Understanding what } \\
\text { constitutes engaged enquiry. }\end{array}$ \\
\hline Hoekstra (2008) & $\begin{array}{l}\text { Use of clickers in lectures in a } \\
\text { chemistry course in USA. }\end{array}$ & $\begin{array}{l}\text { Ethnographic - the meanings students } \\
\text { assign to clickers. Participant }\end{array}$ & $\begin{array}{l}\text { Co-operation in class. A desire to be actively } \\
\text { engaged. Not being anxious about sharing own }\end{array}$ \\
\hline
\end{tabular}


DOI: $10.1108 / S 1479-362820140000012011$ (Permanent URL)

\begin{tabular}{|c|c|c|c|}
\hline & & $\begin{array}{l}\text { observation, survey and interviews over } \\
3 \text { years. }\end{array}$ & ideas. \\
\hline Paper & Leaners and their context & Methods & Learner attributes \\
\hline Holley (2009) & $\begin{array}{l}\text { Widening access students. } \\
\text { Questions focussed on the } \\
\text { personal spaces which learners } \\
\text { create for learning. }\end{array}$ & $\begin{array}{l}\text { Interviews using the biographical } \\
\text { narrative interpretative method. }\end{array}$ & $\begin{array}{l}\text { A framework with three axes: control over } \\
\text { technology used for learning, expectations for } \\
\text { education, and preferences for inhabiting social } \\
\text { spaces. Students at low risk have a good match } \\
\text { between their expectation of education combined } \\
\text { with high control over their home environment and } \\
\text { use of technology. }\end{array}$ \\
\hline $\begin{array}{l}\text { Jeffrey, Bronwyn, } \\
\text { Oriel, Merrolee, } \\
\text { Coburn \& McDonald } \\
(2011)\end{array}$ & $\begin{array}{l}\text { Four higher education institutions } \\
\text { in New Zealand ran } 10 \text { workshops } \\
\text { for staff and students about the use } \\
\text { of digital technology. }\end{array}$ & $\begin{array}{l}\text { Case study design with } 42 \text { participants. } \\
\text { Researcher observations and notes, } \\
\text { focus group interviews, an email forum, } \\
\text { reflective journals, pre- and post- } \\
\text { surveys. }\end{array}$ & $\begin{array}{l}\text { Seven major themes: collaboration, access, } \\
\text { confidence and self-efficacy, time and permission } \\
\text { to play, openness and learning from play, changing } \\
\text { their approach to learning and personal growth. }\end{array}$ \\
\hline $\begin{array}{l}\text { Kear, Woodthorpe, } \\
\text { Robertson \& } \\
\text { Hutchinson (2010) }\end{array}$ & $\begin{array}{l}\text { Open University distance learners } \\
\text { using a wiki for online tutorials. }\end{array}$ & $\begin{array}{l}\text { Questionnaire to students }(n=53) \text { with } \\
\text { open response option, and unstructured } \\
\text { online feedback from tutors. }\end{array}$ & $\begin{array}{l}\text { Some students commented on the value of a wiki } \\
\text { as a tool for creative collaboration e.g. producing a } \\
\text { shared document. }\end{array}$ \\
\hline Lea \& Jones (2011) & $\begin{array}{l}\text { UK undergraduates from a pre- } \\
1992 \text { university, a post- } 1992 \\
\text { university and a further education } \\
\text { college. Questions focussed on } \\
\text { students' literacy practices in } \\
\text { relation to technology for learning. }\end{array}$ & $\begin{array}{l}\text { Interviews with } \mathrm{n}=34 \text { students on 3-4 } \\
\text { occasions over a six month period with } \\
\text { observations of students' use of texts } \\
\text { and technologies. Also 'shadowing' } \\
\text { keeping in contact with short email and } \\
\text { text chats. }\end{array}$ & $\begin{array}{l}\text { The social and cultural contexts that shape literacy } \\
\text { practices. Embracing social networking to gain } \\
\text { support, taking on multiple identities in order to } \\
\text { gain support, separating personal and university } \\
\text { communications. }\end{array}$ \\
\hline $\begin{array}{l}\text { Masterman \& Shuyska } \\
(2012)\end{array}$ & $\begin{array}{l}\text { Postgraduate students from nine } \\
\text { different blended, taught Master's } \\
\text { courses at Oxford University, UK. }\end{array}$ & $\begin{array}{l}\text { Initial survey }(n=77) \text {, reflective survey } \\
(n=65) \text {. Variant of email interviewing } \\
\text { with extended conversations over time } \\
\text { ('pen-pal' method) }(n=23)\end{array}$ & $\begin{array}{l}\text { Students were adept at accessing and evaluating } \\
\text { information and communicating in digital } \\
\text { environments. They implemented strategies to } \\
\text { resist distractions from social tools. }\end{array}$ \\
\hline $\begin{array}{l}\text { Seale, Draffan \& Wald } \\
(2010)\end{array}$ & $\begin{array}{l}\text { UK higher education students with } \\
\text { a disability. Questions focussed on } \\
\text { how disabled learners experience } \\
\text { and participate in technology-rich } \\
\text { learning environments }\end{array}$ & $\begin{array}{l}\text { Participatory approach. Online survey, } \\
\text { interview with artefact, focus group } \\
(n=31) \text {. }\end{array}$ & $\begin{array}{l}\text { Digital agility: being extremely familiar with } \\
\text { technology, using a wide range of strategies, and } \\
\text { having high levels of confidence in their own ability } \\
\text { to use technology. }\end{array}$ \\
\hline $\begin{array}{l}\text { Stein, Wanstreet \& } \\
\text { Calvin (2009) }\end{array}$ & $\begin{array}{l}\text { Students enrolled in a blended, US } \\
\text { graduate-level course on adult } \\
\text { education in American society. }\end{array}$ & $\begin{array}{l}\text { Online chat sessions }(n=15) \text { and in- } \\
\text { depth interviews }(n=5) \text {. }\end{array}$ & $\begin{array}{l}\text { Reducing the transactional distance space by: } \\
\text { creating a voice for learning, connecting in a space } \\
\text { for learning, and creating a time for learning. }\end{array}$ \\
\hline
\end{tabular}


DOI: $10.1108 / S 1479-362820140000012011$ (Permanent URL)

\begin{tabular}{|l|l|l|l|}
\hline $\begin{array}{l}\text { Winter, Cotton, Gavin } \\
\text { \& Yorke (2010) }\end{array}$ & $\begin{array}{l}\text { University staff taking postgraduate } \\
\text { courses in teaching development. }\end{array}$ & $\begin{array}{l}\text { Survey and semi-structured interviews } \\
(\mathrm{n}=10) .\end{array}$ & $\begin{array}{l}\text { Students who used technology effectively for } \\
\text { learning utilised appropriate e-technologies to meet } \\
\text { their own learning needs, used networks to access } \\
\text { support and were effective e-communicators. }\end{array}$ \\
\hline
\end{tabular}




\section{Allocating keywords}

Each paper was allocated keywords. Given the open research question to identify learner attributes associated with effective learning in technology rich environments, keywords arose from the papers themselves. There was no attempt to reinterpret the original data, hence the keywords represent the attributes that had been identified by the authors of the papers, using their original terms. The keywords and their frequency of occurrence are listed in Table 4. It is remarkable that there are 47 keywords arising from just 15 papers, of which most appeared in one paper and none appeared in more than four papers. It is clear that we do not yet share a common terminology for describing the attributes of learners in a digital age.

It is worth noting that the keywords arose in the findings and discussion sections. That is, few of the studies set out to identify the attributes of successful learners. Rather they tended to observe that not all learners responded in similar ways to the environments they were presented with and went on to explore the duality they found between 'some' or 'many' learners. It also seems that successful learners in these environments are still not the norm. Some of the included studies commented that generally students were less IT competent than expected (Masterman \& Shuyska, 2012), not very experienced using e-learning (Winter, Cotton \& Yorke, 2010) or were naïve about the role of technology in learning (Anagnostopoulou, Parmar, \& PriegoHernandez, 2009; Katic, 2008). Indeed, a number of studies that I expected to include were excluded from the final set because they did not find any attributes or practices that were contributing to effective learning in digital environments. This included Katic's (2008) study of conceptions of technology in trainee teachers, where neither of the participants recognised the potentially transformative impact of technology for education, and Ferguson's (2010) evaluation, which uncovered only negative experiences of using online forums in a distance learning setting.

Table 4. List of keywords to describe characteristics of effective learners in technology enhanced learning environments and number of papers allocated this keyword.

\begin{tabular}{|l|c|}
\hline Keywords. & $\begin{array}{c}\text { Number of papers allocated } \\
\text { this keyword }(\mathrm{n}=18)\end{array}$ \\
\hline Active learning & 2 \\
\hline Adaptability & 1 \\
\hline Affiliation & 1 \\
\hline Affordances & 3 \\
\hline Agility & 1 \\
\hline Belief & 1 \\
\hline Boundaries & 1 \\
\hline Camaraderie & 1 \\
\hline Collaboration & 2 \\
\hline Communication & 2 \\
\hline Conceptions & 2 \\
\hline Confidence & 3 \\
\hline Connections & 2 \\
\hline Contribution & 2 \\
\hline Control & 1 \\
\hline Co-operation & 1 \\
\hline Critical engagement & 1 \\
\hline Deep approach & 4 \\
\hline Distraction & 3 \\
\hline
\end{tabular}




\begin{tabular}{|l|l|}
\hline e-communication skills & 1 \\
\hline e-research skills & 1 \\
\hline Engagement & 1 \\
\hline Expectations & 1 \\
\hline Experimentation & 1 \\
\hline Fluency & 1 \\
\hline Gender & 1 \\
\hline Help-seeking & 2 \\
\hline Identity & 1 \\
\hline Incidental learning & 1 \\
\hline Information literacy & 3 \\
\hline Initiating & 1 \\
\hline Inquisitive & 1 \\
\hline Intentionality & 1 \\
\hline Metacognition & 2 \\
\hline Networks and networking & 2 \\
\hline Openness & 2 \\
\hline Participation & 1 \\
\hline Personalisation & 2 \\
\hline Playfulness & 1 \\
\hline Prior experience & 2 \\
\hline Prioritisation & 1 \\
\hline Reflection & 2 \\
\hline Resourcefulness & 1 \\
\hline Sharing & 3 \\
\hline Sociability & 1 \\
\hline Space & 1 \\
\hline Voice & 1 \\
\hline
\end{tabular}

\section{Developing themes for analysis}

Finally the findings sections of each of the 15 papers were coded against the keywords, and themes were allowed to emerge. This allowed for expansion of the themes and iterative levels of interpretation. The keywords enabled searching of the Endnote database for the relevant literature on each learner attribute. Table 5 shows how themes emerged over the iterative interpretations of the findings in response to multiple readings, using memos, annotations and sketches. The second order interpretations largely draw on the concepts identified by the original authors. The challenge between the second and subsequent order interpretations was to move beyond simple categorisation of keywords to reveal a subtext which cuts across the initial overarching concepts. The fourth order interpretations return to the core issue of attributes well suited to next generation learning environments.

Table 5 Developing levels of interpretation

\begin{tabular}{|l|l|l|l|}
\hline $\begin{array}{l}\text { Overarching } \\
\text { concepts }\end{array}$ & $\begin{array}{l}\text { Second order } \\
\text { interpretations }\end{array}$ & Third order interpretations & $\begin{array}{l}\text { Fourth order } \\
\text { interpretations }\end{array}$ \\
\hline $\begin{array}{l}\text { Learning } \\
\text { approach }\end{array}$ & $\begin{array}{l}\text { Deep } \\
\text { Collaborative } \\
\text { Reflective } \\
\text { Networked } \\
\text { Active } \\
\text { Co-operative }\end{array}$ & $\begin{array}{l}\text { Understanding and making } \\
\text { use of the potential of new } \\
\text { technology for: } \\
\text { - Activity }\end{array}$ & \\
& \multicolumn{2}{|l}{} & \\
\hline
\end{tabular}




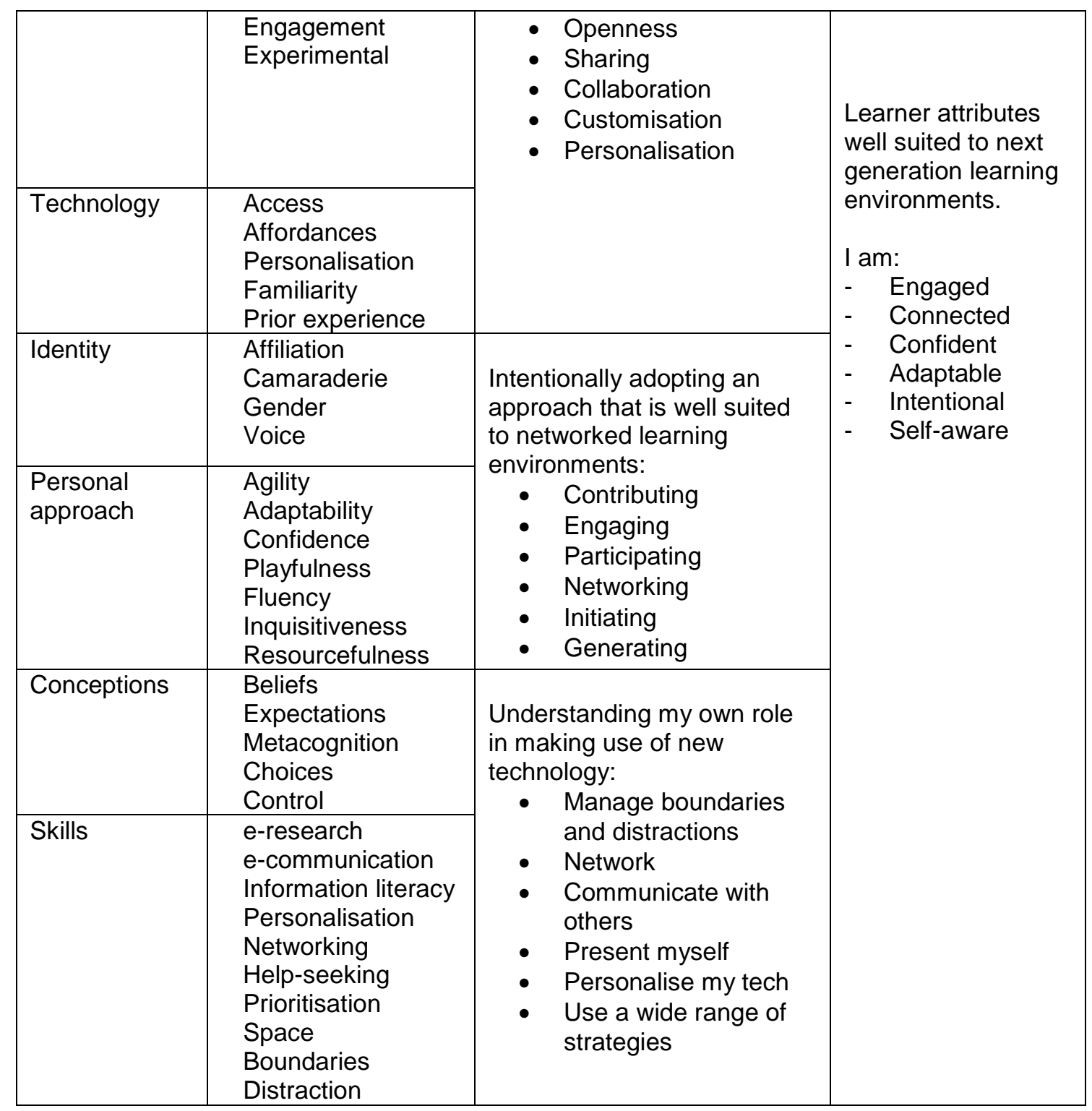

\section{Findings and discussion}

The analysis resulted in six attributes that describe students who thrive in next generation learning environments. The discussion that follows explores the evidence for these attributes and what they each mean within the context of next generation learning environments. Returning to the original studies allows these attributes to be expanded and illustrated with examples, with an emphasis on those expressed in the words of learners themselves.

\section{Engaged}

What does it mean to be an engaged learner within next generation learning environments? Being engaged was variously described as being active (Anagnostopoulou et al., 2009), actively engaged (Hoekstra, 2008), or critically engaged (Ellis et al., 2012). Some studies also referred to the need for learners to contribute or participate (Dujardin, 2009; Anagnostopoulou et al., 2009 and Brown \& Czerniewicz, 2007). In addition Brown et al., (2013), Buckley et al., (2010) and 
Masterman and Shuyska (2012) noted that many of the students they worked with exhibited characteristics of a deep approach to learning.

Ellis et al. (2012) offered the most systematic investigation of engagement in their phenomenographic analysis of interviews with students who had experienced various kinds of enquiry-based learning. They found that what distinguished students was their understanding of what constitutes engaged enquiry, specifically 'learning through enquiry by being 'active, critically engaged and aware of the value of authentic contexts/discovery processes' (p.617). Here engagement is not just for its own sake, rather learners with this conception 'engaged sufficiently with the experience to discover what the real knowledge is in order to participate effectively' (p. 618). Although Ellis et al. specifically related engagement to enquiry based tasks, there are clear parallels here with other types of learning activities. For example, Hoekstra (2008) found that some students talked about their desire to be actively engaged when using clickers in lectures.

\section{Connected}

What does it mean to be a connected learner within next generation learning environments? Around half of the studies mentioned being adept at communicating in digital environments as important to their learners (Brown et al., 2013; Masterman \& Shuyska, 2012; Winter et al., 2010; Dujardin, 2009; Andrews \& Tynan, 2012; Stein, Wanstreet, \& Calvin, 2009; Lea \& Jones, 2011). It is not just that students must be skilled at e-communications, they must also be well connected and value these interactions. Being skilled includes issues of voice, identity and awareness of selfpresentation. Making use of networks for informal support is also a significant feature of this attribute.

Dujardin (2009) described her single fluent e-learner as 'fluent in her online presentation, she valued her interactions with others and contributed to the overall sociability of the VLE'. For Stein et al. (2009) creating 'a voice for learning' was a significant part of reducing transactional distance for novice online learners.

Winter et al. (2010) also identified being a good e-communicator as important, where these skills were used to sustain relationships with colleagues, facilitate learning through academic networks and gain support through formal and informal channels, as in this example:

"I hassle people [through email] for help with the things I am stuck on. There are also a lot of mailing lists that you can get information from." (Winter et al., p.76)

Andrews and Tynan (2012) reported that being able to participate in informal networks was highly valued by students, particularly for accessing help on technical issues. Indeed, connectedness was a key theme in their study, defined as 'students' ability to interact with each other, their lecturers and the institution' (p.571). Andrews and Tynan noted that students made use of both institutionally supported and personal technologies to do this. This example was of students working together informally to prepare for an individually assessed task:

'Log into Facebook and Skype to see what others are doing - we have a quiz for one of the units that we decide that we'll try and do together this afternoon.. ' (Andrews \& Tynan, p. 574)

The use of informal networks was explored in more detail by Lea and Jones (2011) who found students embraced social networking in order to gain support. Here 
students took on multiple identities in order to gain support and worked in ways which protected each other and the connections they had built.

Making use of support was a key theme for Brown et al. (2013). Here students who sought support did so not only from peers, they also expressed a desire to have contact with lecturers for the purpose of discussion, reassurance and feedback

\section{Confident}

Even if students adopt an engaged approach to their learning, and value and use the connections they have with others, it seems they need something else in order to take the extra step and make use of the technology, networks and learning tasks available to them. This was described by some studies as confidence to use technology (Seale et al., 2010); Jeffrey et al., 2011); Masterman \& Shuyska, 2012), and by others as a willingness to initiate interaction (Brown et al. 2013) or a willingness to share (Jeffrey et al., 2011; Hoekstra, 2008; Kear et al., 2010).

For Seale et al. (2010) confidence in one's own ability to use technology was an important element of their notion of digital agility. For Jeffrey et al. (2011) confidence with technology use also included digital identity and privacy. However, it is recognised that confidence in using technology is the most problematic of the attributes explored in this chapter. Students frequently overestimate their own confidence and self reported confidence does not relate well with appropriate technology use. This was illustrated well by Masterman and Shuyska (2012) in their discussion of confidence

'Educ81 initially confessed 'I generally don't not have much confidence in my technology abilities', but was adopting a wide range of technologies in her dissertation fieldwork' (Masterman \& Shuyska, 2012, p. 348)

A willingness to share with others was expressed in a number of studies including not being anxious about sharing own ideas when co-operating with classmates in lectures that used clickers (Hoekstra, 2008). Jeffrey et al. (2011) expressed such willingness to share as 'The collaborative process revealed the importance of a particular disposition underpinning digital and information literacy, namely sharing' ( $p$. 397).

\section{Adaptable}

Being adaptable can be described as having a wide range of strategies on which to draw (Seale et al. 2010; Anagnostopoulou et al., 2009), a resourcefulness to overcome challenges and prioritise competing demands (Andrews \& Tynan, 2012; Holley, 2009), and/or a tendency to experiment with technology (Jeffrey et al., 2011; Masterman \& Shuyska, 2011; Seale et al., 2010). Interestingly, being adaptable seemed to enable students to develop the strategies they needed in order to use technology in ways that met their own individual learning needs.

Anagnostopoulou et al. (2009) found that learners who persisted were aware of how they learnt in a wide range of situations and had strategies to draw on. Seale et al. (2010) in their study of disabled learners listed the wide range of strategies that each individual learner had developed. Here learners described how they used experimentation or trial and error in order to learn how to use a new tool:

"I'd just use it - trial and error. l'd possibly ask my peers, but as I'm quite good with computers, I can just get stuck in.. Most of the time I would probably just have a play." (Seale et al., 2010, p.453) 
Such experimentation was also highlighted by Jeffrey et al. (2011). This learning from experimentation was related to the time given to play, but also to an attitude to being open to learn new things in a new way:

"I just click here and oops that isn't what I wanted, so I do a lot of that and I find it quite helpful. You learn something every time you go around and around the menus" (Jeffrey et al., 2011, p.403)

For both Andrews and Tynan (2012) and Holley (2009), being resourceful meant being able to combine and prioritise the competing demands of education, work and family life. Indeed, part of the reason students need to be adaptable is to find solutions for their own individual learning needs (Andrews \& Tynan, 2011; Seale et al. 2010; Winter et al., 2010).

\section{Intentional}

The attribute of intentionality arose from an inspection of the examples of strategies that were given in the papers and the degree of choice that learners exerted. It seems to be important that learners are aware of their own agency in the learning process and that they know that they need to take action. While there were many examples of effective strategies it was the intent with which they are adopted which is of interest here. For example Winter et al. concluded that students who used technology effectively for learning recognised and utilised technologies to meet their own learning needs.

Another good example is the support seekers in Brown et al.'s study, who demonstrated early engagement with the online learning environment and regular contribution to online discussion forums. In order to achieve the desired levels of engagement they intentionally introduced strategies to help, such as creating mobile phone alerts whenever new posting were made. Similarly, a participant in the Jeffrey et al. study described how she tried to keep up with everyone else's blogs once a week. Andrews and Tynan (2012) reported that several students 'made a deliberate decision' to purchase mobile technologies to support their desire to access learning materials on the move.

Intentional strategies might go against the advice or expectations of lecturers and institutional guidance. Lea and Jones (2011) discussed in some detail students' preferences for instant messaging and personal email, even when they had been explicitly asked to use the institutional virtual learning environment. Student choices even extend to not using technology when it suited them better not to (Masterman \& Shuyska, 2012; Winter et al, 2010). Winter et al. explored this specifically in relation to managing boundaries and distractions, where one student explained:

"No, of course I do not have my computer on when I am trying to learn because sometimes it distracts me because I have the Messenger on or I will read the newspapers and I don't like that if I am trying to learn". (Winter et al, 2010, p.78)

\section{Self-aware}

An awareness of one's own learning is important whether the context is technological or not. Anagnostopoulou et al. (2009) illustrated this, finding that students who persisted at university demonstrated an awareness of how they learn as individuals. In Ellis et al.'s study it was seen to be important that learners were aware of the 
'intrinsic value' of learning contexts. This metacognition was well expressed by one of their interviewees:

"I find it easier to understand things if you do things hands-on, rather than just copying it out from a text book or learning things by rote learning, that sort of thing" (Ellis et al, 2012, p. 617)

In technological contexts, such an awareness of one's own learning needs to be complemented by an understanding of the affordances of the technology. Seale et al. (2010) report that the most frequently given reason for a particular technology use was whether students perceived it to support their learning or socialising.

Four of the studies referred to students' conceptions of discussion forums (Winter et al. 2010; Buckley et al, 2010; Dujardin, 2009; Stein et al., 2009). Winter et al. found that students with previous experience of online asynchronous discussions recognised the 'opportunities for reflection, expressing opinion and sharing ideas' ( $p$. 77). Buckley et al. (2010) reported that students understood that discussion forums were a place where 'drawing on the experiences of others could help them to develop and learn new skills', and a place where they could share personal experiences and reflect upon themselves as learners. Dujardin's single 'fluent' elearner said

"It is very good to post the task to a forum where students can discuss each other's thoughts and point out issues that other students might miss otherwise."

Similarly Stein et al. (2009) explained how, as the course progressed, the fictional single learner 'Pat' came to understand the role of the discussions in knowledge creation:

In this particular class, the dialogue caused us, I think, to really think through an issue because you weren't just making one-way communication, doing research and throwing it back out there. You were being challenged daily by your classmates to try and put something positive together and by the people [in] the other [groups]. (Stein et al, 2009, p. 308)

Effective learning also requires a self-awareness of the need to create times and spaces for learning. Holley (2009) recognised that learners do much to create their own spaces, finding that it is important that leaners have high control over their home environment and use of technology. Stein et al. (2009) saw creating a time for learning as a key theme. For them, this meant prioritising and organising home life and study to accommodate online tasks.

\section{Conclusions}

Although models of digital literacy have recently started to make reference to learner attributes alongside skills and practices, few studies have set out to study the attributes of learners who are effective in next generation learning environments. Learner experience research, which uses qualitative methods to generate rich descriptions of learners' perspectives, has already shown the value of learning from learners themselves. Learning experience research can make a valuable contribution to our search for attributes that might characterise effective learners. Therefore this chapter used a meta-analysis technique to interpret the findings from existing learner experience research studies. The initial reading and allocation of keywords showed that researchers do not yet share a common terminology for describing the attributes of learners in a digital age. There is a need for more sharing and collaboration of the kind that takes place between researchers who are members of the ELESIG community $^{3}$. It would be worthwhile now to use the methods developed by learner 
experience researchers to explore learner attributes in order to expand our models of digital literacy.

This review was deliberately interpretative in nature, developing iterative levels of interpretation to reduce the initial 47 keywords to 6 key attributes. Although it is unlikely to be the only way of representing the findings from these 15 studies, the review conceptualises those students who learn well as those who are engaged, connected, confident, adaptable, intentional and self-aware. I would suggest that being engaged and self-aware are applicable in all learning contexts. However, this review also hints that technology may be changing what it means to be a successful learner. While it might be argued that being confident, adaptable and intentional are also characteristics of good learners, it would be worthwhile to investigate in more detail how these attributes differ between traditional and next generation learning contexts. The attribute that might be especially worthy of further interrogation is 'connected'. For example, what does it mean to be connected as a learner and how does it differ from being social in more traditional learning spaces?

Finally, it was noted at the outset that context is enormously important in determining how students behave. This chapter sets a challenge for teachers, learning technologists, librarians and instructional designers to work to design learning activities which encourage and reward the development of these attributes.

\section{Notes}

${ }^{1}$ For details on the JISC Learner Experience Programme see http://www.jisc.ac.uk/whatwedo/programmes/elearningpedagogy/learnerexperience.a spx

2 Here 'attributes' are taken to mean the qualities or characteristics of the learner.

${ }^{3}$ ELESIG is an international community of educational researchers and practitioners who are involved in investigations of learners' experiences and uses of technology in learning. See http://www.elesig.net

\section{Acknowledgements}

Thanks to the anonymous reviewer and to my colleague Helen Beetham, who both provided valuable feedback on an earlier draft of this chapter.

\section{References}

Ala-Mutka, K. (2011). Mapping Digital Competence: Towards a Conceptual Understanding. Seville: JRC-IPTS.

Anagnostopoulou, K., Parmar, D. \& Priego-Hernandez, J. (2009). An exploration of the perceptions of learning and e-learning. Brookes eJournal of learning and teaching, 2(4). Retrieved 12 April 2013 from http://bejlt.brookes.ac.uk/

Andrews, T. \& Tynan, B. (2012). Distance learner : connected, mobile and resourceful individuals. Australian Journal of Educational Technology, 28(4), 565-579.

Biggs, J. B. (1989). Approaches to the enhancement of tertiary teaching. Higher Education Research and Development, 8(7-25).

Brown, C. \& Czerniewicz, L. (2007). If we build it will they come? Investigating the relationship between students' access to and use of ICTs for learning. South African Journal of Higher Education., 21(6), 732-747.

Brown, M., Hughes, H., Keppell, M., Hard, N. \& Smith, L. (2013). Exploring the disconnections: student interaction with support services upon 
commencement of distance education. FYHE International Journal, 4(2), 6374.

Buckley, C. A., Pitt, E., Norton, B. \& Owens, T. (2010). Students' approaches to study, conceptions of learning and judgements about the value of networked technologies. Active Learning in Higher Education, 11(1), 55-65.

Cabeza, R. \& Nyberg, L. (2000). Imaging cognition II: An empirical review of 275 PET and fMRI stdies. Journal of Cognitive Neuroscience, 12, 1-47.

Crisp, G. (2014). Assessment in Next Generation Learning Spaces. In K. Fraser (Ed.), The future of learning and teaching in next generation learning spaces (Vol. 12). Bingley, United Kingdom: Emerald Group Publishing.

Dujardin, A.-F. (2009). Conversations with an e-learner. Brookes eJournal of Learning and Teaching, 2(4).

Edmunds, R., Thorpe, M. \& Conole, G. (2010). Student attitudes towards and use of ICT in course study, work and social activity: a technology acceptance model approach. British Journal of Educational Technology,

Ellis, R. A., Bliuc, A. M., \& Goodyear, P. (2012). Student experiences of engaged enquiry in pharmacy education: digital natives or something else? Higher Education, 64(5), 609-626.

Ferguson, R. (2010). Peer interaction: the experience of distance students at university level. Journal of Computer Assisted Learning, 26(6), 574-584.

Hoekstra, A. (2008). Vibrant student voices: exploring effects of the use of clickers in large college courses. Learning, Media and Technology, 33(4).

Holley, D. L. (2009). Spaces and places: negotiated learning in the context of new technology. (Doctor of Philosophy), institute of Education, London.

Jeffrey, L., Bronwyn, H., Oriel, K., Merrolee, P., Coburn, D. \& McDonald, J. (2011). Developing digital information literacy in higher education: obstacles and supports. Journal of Information Technology Education, 10, 383-413.

Katic, E. K. (2008). Preservice teachers' conceptions about computers: an ongoing search for transformative appropriations of modern technologies. Teachers \& Teaching, 14(2), 157-179.

Kear, K., Woodthorpe, J., Robertson, S. \& Hutchison, M. (2010). From forums to wikis: Perspectives on tools for collaboration. Internet \& Higher Education, 13(4), 218-225.

Kirkwood, A. \& Price, L. (2005). Learners and learning in the 21st century: What do we know about students' attitudes and experiences of ICT that will help us design courses? Studies in Higher Education, 30(3), 257-274

Lea, M. R. \& Jones, S. (2011). Digital literacies in higher education. Exploring textual and technological practice. Studies in Higher Education, 36(3).

Liao, H.-L. \& Lu, H.-P. (2008). The role of experience and innovation characteristics in the adoption and continued use of e-learning websites. Computers \& Education, 51(4), 1405-1416.

Liaw, S.-S. (2008). Investigating students' perceived satisfaction, behavioral intention, and effectiveness of e-learning: A case study of the Blackboard system. Computers \& Education, 51(2), 864-873.

Ling, P., \& Fraser, K. (2014). Pedagogies for Next Generation Learning Spaces: context, theory, action. In K. Fraser (Ed.), The future of learning and teaching in next generation learning spaces (Vol. 12). Bingley, United Kingdom: Emerald Group Publishing.

Masterman, E. \& Shuyska, J. A. (2012). Digitally mastered? Technology and transition in the experience of taught postgraduate students. Learning, Media \& Technology, 37(4), 335-354. 
Noblit, G. W. \& Hare, R. D. (1988). Meta-ethnography: Synthesizing Qualitative Studies. Newbury Park, CA: Sage.

SCONUL. (1999). Seven Pillars of Information Literacy. (30 April 2009).

SCONUL. (2012). Seven Pillars of Information Literacy through a digital literacy lens Retrieved 12 April 2013, from http://www.sconul.ac.uk/tags/digital-literacy

Seale, J., Draffan, E. A. \& Wald, M. (2010). Digital agility and digital decision-making: conceptualising digital inclusion in the context of disabled learners in higher education. Studies in Higher Education, 35(4), 445 - 461.

Sharpe, R. \& Beetham, H. (2010). Understanding students' uses of technology for learning: towards creative appropriation. In R. Sharpe, H. Beetham \& S. De Freitas (Eds.), Rethinking Learning for a Digital Age: How learners are shaping their own experiences (pp. 85-99). London and New York: Routledge.

Sharpe, R. \& Savin-Baden, M. (2007). Learning to Learn through Supported Enquiry. A literature review conducted for the L2L through supported enquiry FDTL5 project. A.

Stein, D. S., Wanstreet, C. E. \& Calvin, J. (2009). How a novice online adult learner experiences transactional distance. Quarterly Review of Distance Education, 10(3), 305-311.

Winter, J., Cotton, D., J., G. \& Yorke, J. (2010). Effective e-learning? Multi-tasking, distractions and boundary management by graduate students in an online environment. ALT-J: Research in Learning Technology 18(1), 71 - 83. 